\title{
A review : The development of double row spacing to improve land productivity and income of rubber smallholders
}

\author{
Sahuri*, Risal Ardika, Radite Tistama, and Fetrina Oktavia \\ Indonesian Rubber Research Institute \\ Jl. Raya Palembang-Pangkalan balai Km 29, Palembang 30953, South Sumatra, Indonesia
}

\begin{abstract}
Low prices of rubber has been a serious problem to rubber smallholders in Indonesia. Rubber-based intercropping systems offers a practical solution to this issue and increasing overall productivity of intercrops, for example upland rice and maize. This study reviewed the suitable spatial arrangements in rubber planting to long term impact based intercropping systems. A field experiment was established in a smallholder rubber plantation in Tanah Laut Regency, South Kalimantan with area of 50 ha. Two planting patterns of rubber PB 260 clone were tested: (1) single row planting pattern (SR) by $6 \mathrm{~m} \times 3 \mathrm{~m}$, and (2) double row planting pattern (DR) by $18 \mathrm{~m} \times 2 \mathrm{~m} \times 2.5 \mathrm{~m}$. The experiment showed that girth of rubber trees in the SR system at the first tapping year was slightly larger than in DR system, even though statistically it was not significant. The latex yield per tree of SR and DR systems were similar, however, latex yield per hectare of SR system was higher than DR system due to a higher tree population in SR system. The DR system was technically suitable for long term intercropping, because when rubber tree can reached 8 to 9 years old and light penetration was more than $80 \%$ at distance from the rubber row. The total area required for rubber, upland rice and maize grown in monoculture to produce an equivalent of a one hectare of rubber-upland rice-maize intercrop is 1.87 . This means the intercropping has an advantage compared to monoculture.
\end{abstract}

Keywords: Intercropping system, rubber planting pattern, spatial arrangement

\section{Introduction}

Rubber is an important commodity in Indonesia, especially in Sumatra and Kalimantan. Farmers choose rubber as main crop because it is easy to grow, yield can be stored for long period, rubber can be grown in low fertility soil, and provide daily income [1]. Low prices of rubber has been a serious problem to rubber smallholders in Indonesia [2]. Rubber-based intercropping systems offers a practical solution to this issue and increasing overall productivity $[3,25]$.

*Corresponding author: sahuri_agr@ymail.com 
Benefits of intercropping system between rubber and intercrops compared to monoculture system of rubber are as follows: 1) low weed growth in rubber area [4, 5, 6, 7]; 2) larger girth rubber in intercroping system $[8,9,10,11,12]$; 3) increased yiled of rubber [13,14]; 4) increase in soil organic matter [15, 16]; and 5) increased farmers income [2, 10, 17].

Generally, Indonesia farmers plant rubber using single row with a planting distance of 6 $\mathrm{m} \times 3 \mathrm{~m}$ (550 trees / ha), or $7 \mathrm{~m}$ x $3 \mathrm{~m}$ (476 trees / ha) $[1,6,10]$. Under these planting system, intercrops can only be planted until rubber plants are 1 to 2 years old $[18,6,7,10]$, as the canopies of adjacent rows would have closed by then and the light is light intensity under the canopy would only be $50-60 \%[19,20]$. The area that can be used for intercropping is around $50-60 \%$ of rubber total area [19]. Intercrops such as upland rice, maize, and soybean when planted in more than $50 \%$ shade can have up to $60 \%$ yield reduction as compared to open conditions $[10,19]$. Therefore, modification of rubber palnting system double spacing should be tested $[6,18,21]$. Double plant spacing will allow more sunlight to intercept between rubber row $[6,21,22]$.

Double spacing is also suitable for long term rubber intercropping due to higher sunlight penetration $[6,21,22]$. Double plant spacing of $14.1 \mathrm{~m} \times 2.4 \mathrm{~m} \times 2.4 \mathrm{~m}$ (500 trees / ha), will alow intercropping up to five years with light intensity arround $70-80 \%$ of open area [21]. Double spacing of $20 \mathrm{~m} \times 4 \mathrm{~m} \times 2 \mathrm{~m}$ (416 trees / ha) can be planted with with intercrops throughout life cycle of rubber plants [18]. The area with double plant spacing of $18 \mathrm{~m} \times 2.5$ $\mathrm{m} \times 2 \mathrm{~m}$ (400 trees / ha) can be planted with intercrops longer and more resistant to high wind speed [17].

This study was aimed to reviews the suitable spatial arrangements in rubber planting to long term impact based intercropping systems.

\section{Material and method}

\subsection{Study site and treatments}

Research was carried out in 50 ha farm in Batu Ampar Village, Tanah Laut Regency, South Kalimantan Province from 2008 to 2017. Study used two planting pattern systems, namely: (1) single row planting pattern (SR) with $6 \mathrm{~m}$ distance between rows and $3 \mathrm{~m}$ between plants for a population of 550 trees $\mathrm{ha}^{-1}$; (2) double row planting pattern (DR) with $18 \mathrm{~m}$ distance between duble rows, $2 \mathrm{~m}$ between row, and $2.5 \mathrm{~m}$ between plants with in a row for a population of 400 trees ha-1 (Figure 1). 


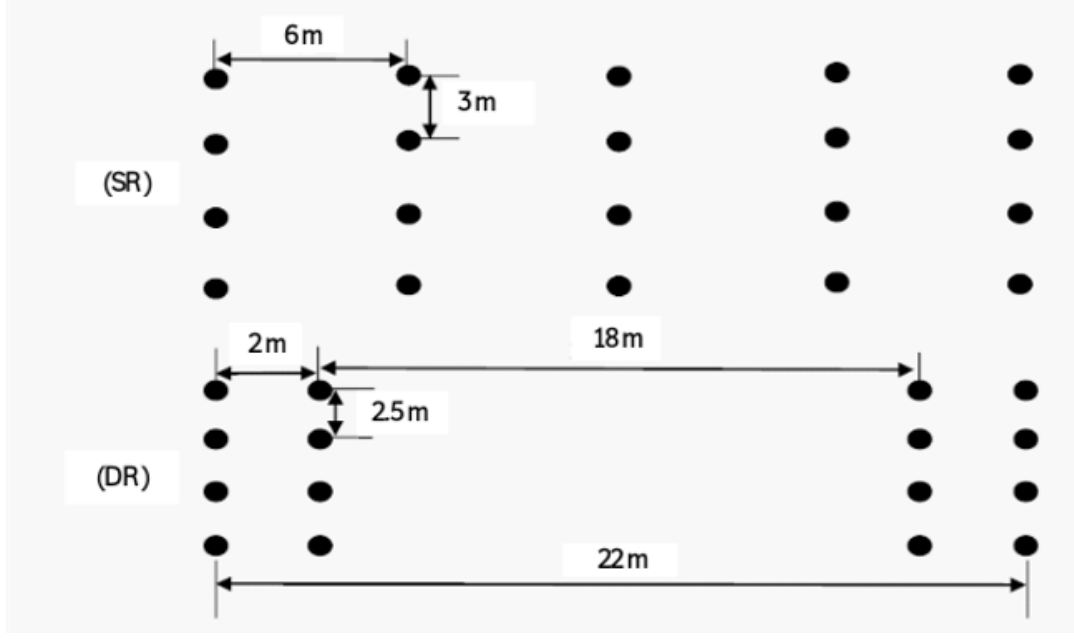

Fig. 1. Experiment layout of rubber planting patterns system: (1) single row (SR); and (2) double row (DR)

Observation of rubber trees using simple random sampling method, comparing SR and DR system rubber trees with number of sample are 120 trees per plot. Rubber plants data were observed i.e, rubber girth from 1 to 8 years after planting (YAP), bark thickness of 8 YAP using caliper to measure distance between bark outest layer and cambium layer, rubber yields of 7 and 8 YAP, and light penetration using LI-COR Line Quantum Sensor. The light penetration was measured by comparing light intensity in the place under rubber canopy and in the place without rubber canopy. The measurement of light penetration was replicated three times. Tapped rubber plants are plants that have a trunk $45 \mathrm{~cm}$, measured $100 \mathrm{~cm}$ from the ground. Tapping system was used a half spiral system that was tapped every 2 days for a year of tapping, namely $\left(1.2 \mathrm{~S}^{-1}\right.$. D2 $\left.2^{-1}\right)$. Rubber yield per hectare was calculated in grams/tree/tapping $\left(\mathrm{g} \cdot \mathrm{t}^{-1} \cdot \mathrm{t}^{-1}\right)$ multiplied by the number of tapped populations per Ha and the total effective tapping days for one year (150 days). Intercrops experiment using two cropping patterns, namely (1) planting patterns of corn using Pioneer varieties and (2) upland rice planting patterns using Inpago varieties. The experiment was arranged in a split plot design with three replications. The main plot of the experiment was rubber spacing system consisted of single row planting pattern (SR) and double row planting pattern (DR). The sub plot of the experiment was two planting patterns consisted of upland rice and maize. Planting distance of maize is $80 \mathrm{~cm} \mathrm{x} 20 \mathrm{~cm}$ (population 62,500 plants ha-1) and upland rice is $40 \mathrm{~cm}$ $\mathrm{x} 10 \mathrm{~cm}(250,000$ plants ha-1). Number of cooperators of upland rice and maize is 25 farmers each. Intercrop yield measured were upland rice and maize production of 1 to 3 years of rubber. The plot area of upland rice and maize is $500 \mathrm{~m}^{2}$ each crops between rubber plants. Soil cultivation is carried out on each plot with minimum tillage and weed cleaning. Plot distance from rubber plant is $1 \mathrm{~m}$.

\subsection{Data analysis}

Intercrops data were analyzed by variance, if it was significantly different then continued with the Duncan Multiple Range Test at 5\% level with Statistical Analysis System 9 program. Growth observation such as rubber girth, bark thickness, and rubber production were analyzed using paired samples test [23]. Intercropping advantage was determined using the 
Land Equivalent Ratio (LER) analysis for known plant population density of the intercropping system and compared to known optimum plant population density of monocrop system:

$$
L E R=\sum_{j=I}^{n} \frac{Y j, i}{Y j, s}
$$

$$
\begin{array}{ll}
\mathrm{yj}, \mathrm{i} & =\text { Yield of intercrop component crop j }\left(\mathrm{kg} \cdot \mathrm{ha}^{-1}\right) \\
\mathrm{yj}, \mathrm{s} & =\text { Yield of monocrop component }\left(\mathrm{kg} \cdot \mathrm{ha}^{-1}\right) \\
\mathrm{n} & =\text { Number of component crops }
\end{array}
$$

Table 1. The potential yield of rubber, upland rice and maize in monocropping and intercropping systems.

\begin{tabular}{|c|c|c|}
\hline Cropping system & Plant population density, $\left(\mathrm{ha}^{-1}\right)$ & Yield $\left(\mathrm{kg}^{-h a^{-1}}\right)$ \\
\hline Monoculture & & \\
\hline Rubber & 500 & 1,615 \\
\hline Upland rice & 250,000 & 5,010 \\
\hline Maize & 625,000 & 8,016 \\
\hline Intercropping & 400 & 1,450 \\
\hline Rubber & 125,000 & 2,063 \\
\hline Upland rice & 312,500 & 4,500 \\
\hline Maize & & \\
\hline
\end{tabular}

Remarks : The population and areal of upland rice and maize as rubber intercrops $60 \%$ of monoculture system with a distance of upland rice and maize from the row of rubber trees is $1 \mathrm{~m}$.

\subsection{This is part of discussion and recomendation}

A technology that might be developed is cultivation of rubber with double row spacing i.e. 18 $\mathrm{m} \times 2 \mathrm{~m} \times 2.5 \mathrm{~m}$. Plant population of using this planting distance is 400 trees/ha. Light intensity is still high and enable to grow intercropping system for longer period of time (Figure 2 and 3). To keep the area opened longer, it with be better to growth rubber clone having a pine branching type.

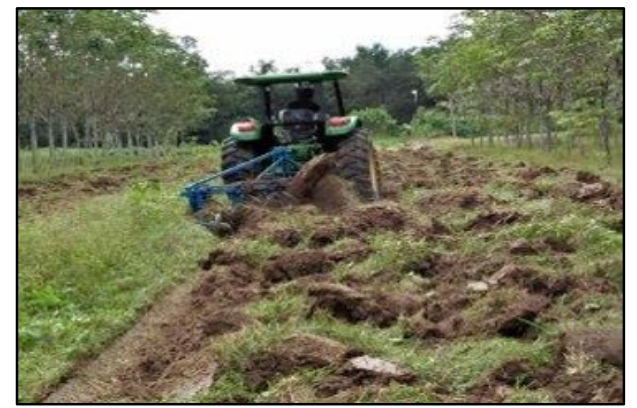

Tillage with tractor

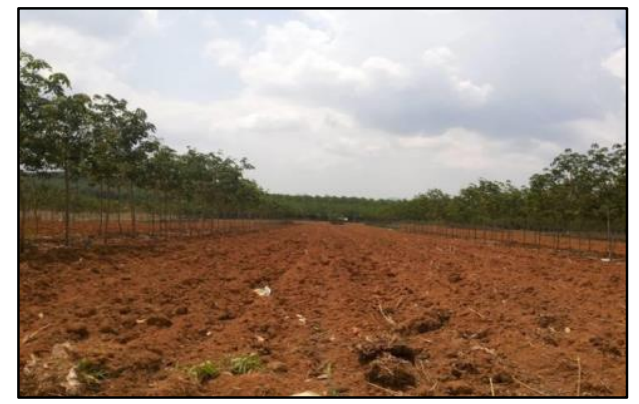

3 years old 


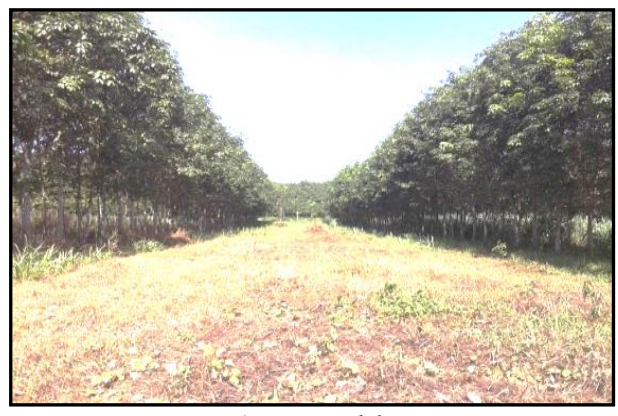

5 years old

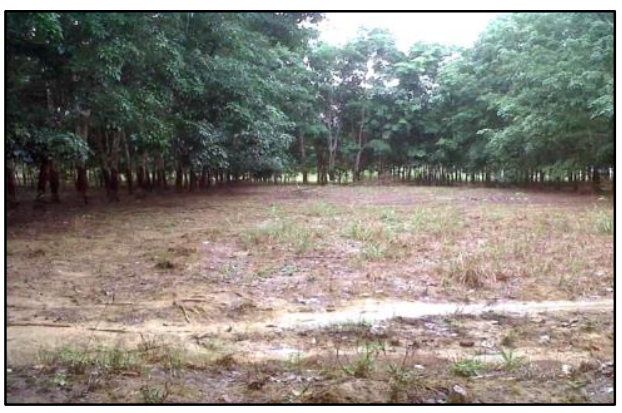

10 years old

Fig. 2. Double wide rows $(18 \mathrm{~m}+2 \mathrm{~m}) \times 2.5 \mathrm{~m}$ at immature stage until mature stage

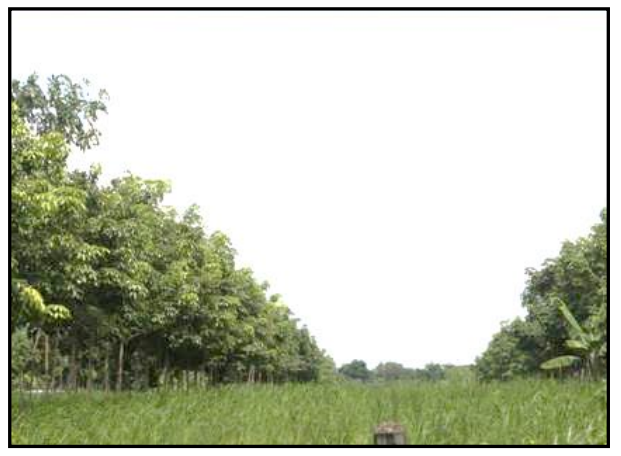

Rubber + upland rice

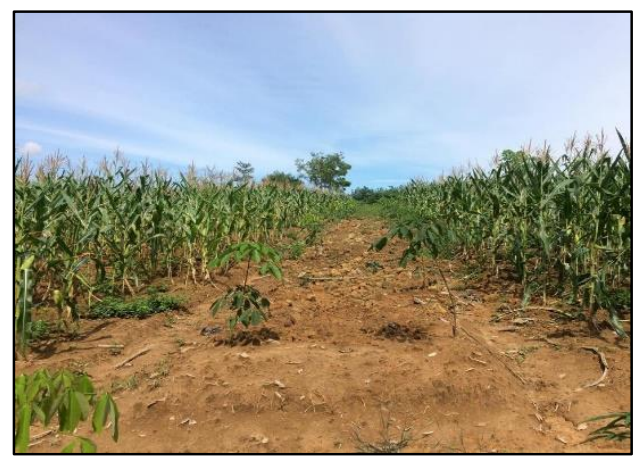

Rubber + maize rice

Fig. 3. Rubber based intercropping with double wide rows $(18 \mathrm{~m}+2 \mathrm{~m}) \times 2.5 \mathrm{~m}$

\section{Results and discussion}

\subsection{Light penetration}

The average light penetration in the center of the SR system is 22.35 (Figure 4) and in the narrow row of the DR system is $15.6 \%$ (Figure 5). This means that the light penetration is not more than $30 \%$ at each point measured on the SR system. Meanwhile, the penetration of light in the DR system is $>80 \%$ within $4 \mathrm{~m}$ of rubber rows. Thus the DR system is more suitable for long term rubber based intercropping. 


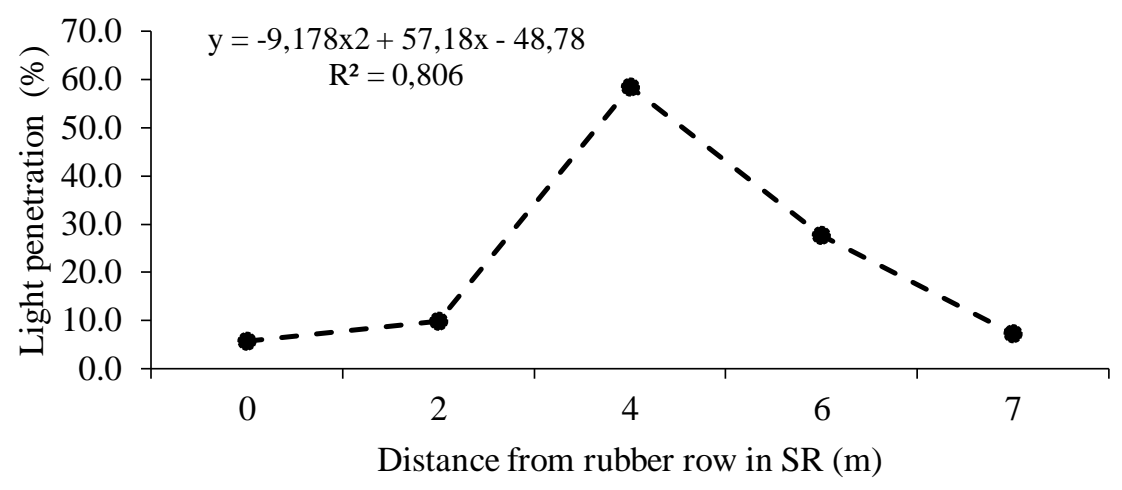

Fig. 4. Light penetration between row of SR system at 8 YAP

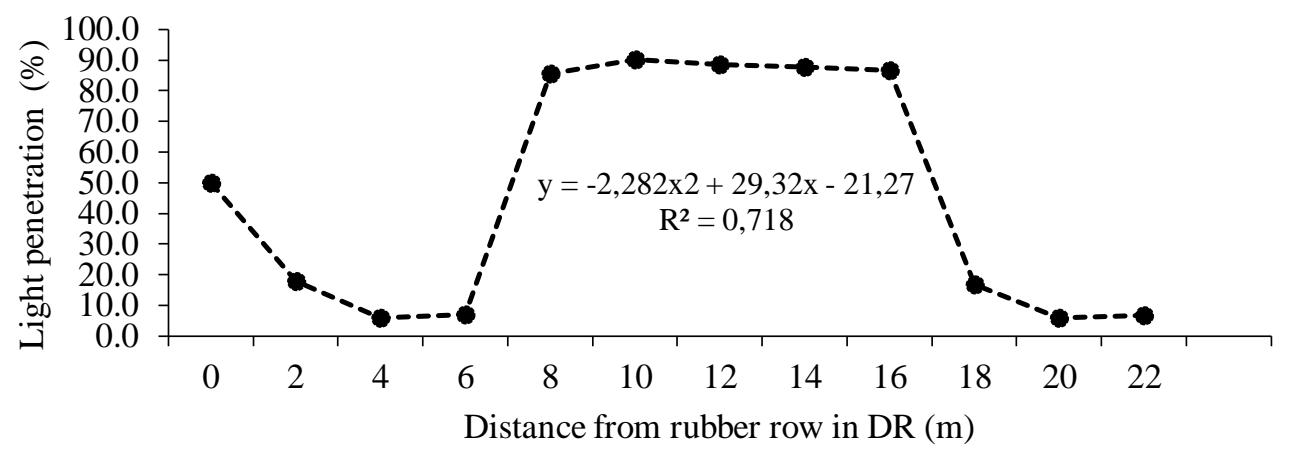

Fig. 5. Light penetration between row of DR system at 8 YAP

The DR system is technically suitable for long term intercropping, because when rubber trees are 8 to 9 year old, light penetration at $4 \mathrm{~m}$ from double row was $>80 \%$. The potential intercropped area of the SR and DR system are $60 \%$ and $80 \%$, respectively. To keep the area between rubber rows open to sunlight growth rubber clone pine branching type of rubber trees can be grown. This is in line with the results of $[3,18,24]$, showed that double spacing is also suitable for long-term rubber intercropping due to higher sunlight penetration and with intercropping up to five years (with light intensity arround $70-80 \%$ of open area), and more resistant to high wind speed.

\subsection{Plant girth}

Rubber in double row planting pattern system (DR) reached maturity at 4.5 years old. Rubber girth on first years of mature period was slightly larger in SR system than in DR system. The rubber at 8 years old was $56.10 \mathrm{~cm}$ and was $55.20 \mathrm{~cm}$, respectively, which were still not statitically different (Figure 6), $(\mathrm{P}=0,484)$. This results are agree with earlier studies $[18$, $21,22]$. 


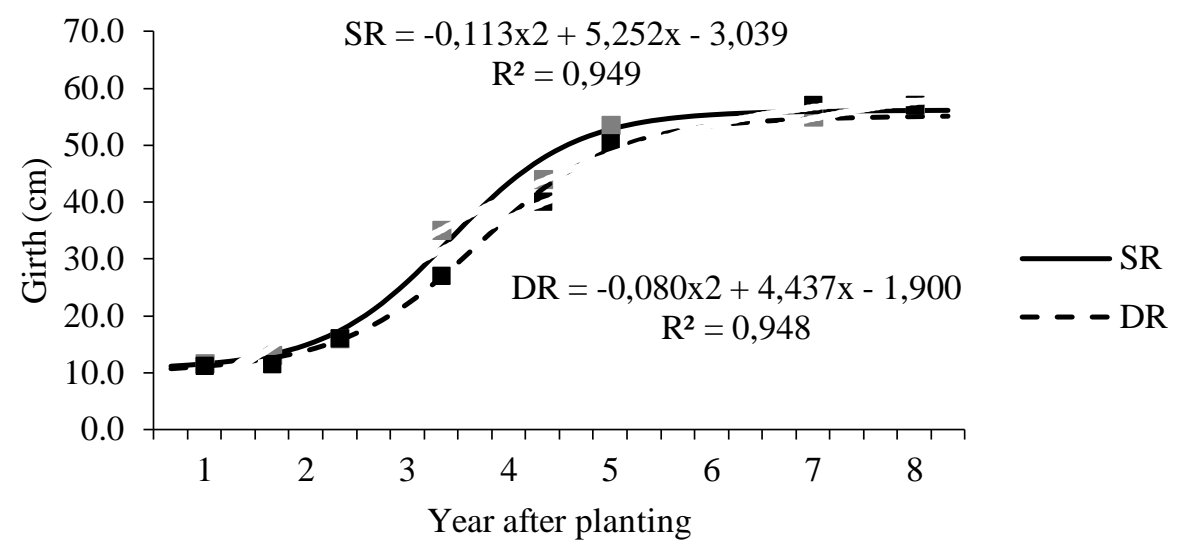

Fig. 5. The effect of planting patterns on rubber girth; single row (SR) planting pattern; double row (DR) planting pattern.

\subsection{Latex yield}

Latex yield per tree under SR and DR system were not significantly different $(\mathrm{P}=0.798)$. However, latex yield per hectare of SR system is significantly higher than DR system (Table 1). This is because SR system population is more than DR system, and latex yield per hectare depends on the latex yield per tree and number of trees per hectare. The differences in population resulted in a significantly higher latex yield of SR system, with a mean difference of $164.40 \mathrm{~kg} \mathrm{ha}^{-1}$ year $^{-1}$ (Table 2).

Table 2. The effect of planting pattern system on latex yield

\begin{tabular}{|c|c|c|}
\hline Planting system & Yield $\left(\mathrm{g} \cdot \mathrm{p}^{-1} \cdot \mathrm{s}^{-1}\right)$ & $\begin{array}{c}\text { Latex yield }\left(\mathrm{kg} . \mathrm{ha}^{-}\right. \\
{ }^{1} \text {.years }\end{array}$ \\
\hline Single row & $23.92 \mathrm{a}$ & $1,614.60 \mathrm{a}$ \\
\hline Double row & $24.17 \mathrm{a}$ & $1,450.20 \mathrm{~b}$ \\
\hline
\end{tabular}

Remarks : Values followed by the same letters within the same column were not significantly different according to DMRT at the 5\%.

*Average production in grams per tree per tapping $\left(\mathrm{g} \cdot \mathrm{t}^{-1} \cdot \mathrm{t}^{-1}\right)$ multiplied by the number of tapped trees per ha and the total effective tapping days in one year (150 days).

With DR system, rubber can be intercrop longer than SR systems. Rubber with SR system can only be intercroped until rubber trees are 2 years old, whereas in DR system, intercroping can be done throughout the productive life of rubber trees. This is because DR system provides more space, sufficient light for intercrop, so DR system can potentially increase overall farm productivity and income of rubber plantations. Higher revenues from intercrops are expected to overcome the decrease in yield due to wider plant spacing and fewer tree population $[18,21,22]$.

\subsection{Land Equivalent Ratio (LER)}

LER was used to determined land productivity. Ratio of area needed under monoculture to a unit area of intercropping at the same management level to give and equal amount of yield $[22,26]$. The total area required for rubber, upland rice and maize grown in monoculture to 
produce an equivalent of a one hectare of rubber-upland rice-maize intercrop is 1.87 (calculation below). This means the intercropping has an advantage compared to monoculture.

$$
\begin{gathered}
L E R=\left(\frac{1,450.2}{1,614.6}+\frac{2,063}{5,010}+\frac{4,500.9}{8,016}\right) \\
=0.89+0.41+0.56 \\
=1.87 \mathrm{ha}
\end{gathered}
$$

Intercropping advantage has been illustrated in many forms, either in monetary economic terms, economic yield, biomass yield or dry matter yield. Land Equivalent Ratio (LER) is the more widely used concept, which is defined as the ratio of area needed under monoculture to a unit area of intercropping at the same management level to give and equal amount of yield $[22,26]$. Intercropping of upland rice and maize with rubber is more productive both in terms of income than monoculture system. This intercropping system can be conducted until two years old of rubber trees for SR system and more than three years for DR system before the light started to be limiting for the intercrop growth.

\section{Conclusion}

The double row system was technically suitable for long term intercropping, because when the rubber tree reached 8 to 9 year old and the light penetration was $>80 \%$ at distance of about $4 \mathrm{~m}$ from rubber tree rows. Economically, double row system can increase the added values for rubber smallholders because it allows long term intercropping scenario. In selecting a suitable farming system, market channels, labour availability and security are the most important socio economic factors in consideration. To extend the period of intercrops cultivation, there is need to modify rubber spacing with double rows of $18 \mathrm{~m} \mathrm{x} 2 \mathrm{~m} \times 2.5 \mathrm{~m}$. To keep the area opened longer, it with be better to growth rubber clone having a pine branching type.

Thank you to Ir. M. Jahidin Rosyid, MS as principal investigator who has provided his valuable input and suggestions in writing this paper. The author gratefully acknowledged the Directorate General of Plantations, District Tanah Laut, for the permits and facilities provided throughout the study.

\section{References}

1. Rosyid, M. J. Indonesian Journal of Natural Rubber Research. 25:25-36(2007).

2. Sahuri and Rosyid, M. J.. Warta Perkaretan. 34:77-88(2015)..

3. Rodrigo, V. H. L., Silva, T. U. K., and Munasinghe, E. S. Field Crops Research. 89:327-335(2004).

4. Pathiratna, L. S. S. Bulletin of the Rubber Research Institute of Sri Lanka. 47:816(2006).

5. Pathiratna, L. S. S., and Perera, M. K. P. Journal of the Rubber Research Institute of Sri Lanka. 87:36-45(2006).

6. Sahuri. Improving rubber spacing system of rubber (Hevea brasiliensis Muell.Arg.) for long-term intercropping. Journal of Indonesia Agriculture. 22:2443-3462(2017a).

7. Sahuri. Jurnal Lahan Suboptimal. 6:33-42(2017b). Sahuri. Indonesian Journal of Natural Rubber Research. 35:23 - 38(2017c).

8. Sahuri. Jurnal Agroteknologi. 8:1- 10(2017d).

9. Sahuri. Jurnal Analisis Kebijakan Pertanian. 15:113-126(2017e). 
10. Ferry, Y., Pranowo, D. and Rusli. Buletin Riset Tanaman Industri. 4:225-230(2013).

11. Tistama, R., Dalimunthe, C. I., Sembiring, Y. R. V., Fauzi, I. R., Hastuti R. D., and Suharsono. Indonesian Journal of Natural Rubber Research. 34:61-76(2016).

12. Ogwuche, P., Umar, H. Y., Esekhade, T. U., and Francis, S. Y. Journal of Agriculture Social Science. 8:100-102(2012).

13. Snoeck, D., Lacotea, R., Kéli, J., Doumbiac, A., Chapuseta, T., Jagoretd, P., and Goheta, É. Industrial Crops and Products. 43:578- 586(2013).

14. Rodrigo, V. H. L., Stirling, C. M., Silva, T. U. K., and Pathirana, P. D. Field Crops Research. 91:23-33(2005).

15. Pansak, W. Kasetsart Journal. 49:785-794(2015).

16. Raintree, J. Agriculture and Forestry Research. 2:41-46(2005).

17. Xianhai, Z., Mingdao, C., and Weifu, L. African Journal of Biotechnology. 11:84848490(2012).

18. Wirnas, D. Pemilihan Karakter Seleksi Berdasarkan Analisis Biometrik dan Molekuler untuk Merakit Kedelai Toleran Intensitas Cahaya Rendah. Disertasi. Sekolah Pasca Sarjana. Insitut Pertanian Bogor. Bogor (2007). [Bahasa Indonesia].

19. Fikriati, M. Adaptation test of soybean (Glycine max (L.) Merr.) shade tolerance under rubber in rubber smallholder in Sarolangun District, Jambi. Skripsi Institut Pertanian Bogor, Indonesia (2010). http://repository.ipb.ac.id/jspui/bitstream/123456789/27130/6/Bab\%20I\%20Pendah ulua n\%20A10dpr-3.pdf.

20. Rodrigo, V. H. L., Silva, T. U. K., \& Munasinghe, E.S. Field Crops Research. 89:327-335(2004).

21. Jalloh, M. B., Sulaiman, W., Harun, W., Talib, J., Ramlan, M. F., Amartalingam, R., Sung, C. T. B., and Ahmed, O.H. A. American Journal of Agricultural and Biological Sciences. 4:249-254(2009)

22. Gomez, K.A. \&A.A. Gomez. Statistical procedures for agricultural research. UI Press. Jakarta, Indonesia (1995).

23. Xiongfei, Y and Nengfa, P. Intercropping patterns and their development in rubber plantations in Dehong District, Yunnan, China in Proceedings of IRRDB Symposium 2004 (C. Qiubo, Z. Jiannan, and Weifu L, eds.), p 183-187, China Agriculture Press (2004)..

24. Weifu, L., Zhongyu, Z. and Shoufeng, H. Jounal of Ecology. 18:43-52(1999).

25. Jalloh, M. B. Modeling of solar radiation interception and biomass production in an intercropping system of rubber with banana and pineapple. $\mathrm{PhD}$ Thesis, University Putra Malaysia (2003). http://webopac.upm.edu.my. 